\title{
Plant Volatiles Inhibit Pollen Germination of Apple and Other Species
}

\author{
Douglas D. Archbold, Thomas R. Hamilton-Kemp, and \\ John H. Loughrin \\ Department of Horticulture and Landscape Architecture, University of \\ Kentucky, Lexington, KY 40546-0091
}

Additional index words. Malus domestica. Prunus avium, P. domestica, plum, sweet cherry, bioassay

French et al. (1979) reported that volatile compounds similar to those known to affect fungal spore germination in vitro affected germination of Pinus spp. pollen. Our objectives in this preliminary work were to screen plant-derived volatile compound mixtures, floral and vegetative, to determine if they influenced germination of pollen from several fruit species.

Apple (Malus domestica Borkh. 'Red Delicious' and 'Golden Delicious'), sweet cherry (Prunus avium L. 'Van'), and plum (P. domestica L. 'Friar') pollen (Antles Pollen Supplies, Wenatchee, Wash.) were stored at $-20 \mathrm{C}$ over anhydrous $\mathrm{CaCl}_{2}$. Aliquots of stamen were rehydrated in $13 \times 100-\mathrm{mm}$ test tubes at room temperature and $100 \%$ relative humidity for $30 \mathrm{~min}$. The tubes were shaken to facilitate pollen release; pollen grains were captured on a camel hair brush and dispersed across the surface of a $1-\mathrm{cm}^{3}$ block of 3\% agar (Sigma, St. Louis) by gently moving the brush across a fine mesh screen. The agar block was placed in an uncovered 5-cm glass petri dish contained within a 9$\mathrm{cm}$ glass petri dish. Selected tissues were then placed around the perimeter of the 5$\mathrm{cm}$ dish, and the cover was placed on the 9$\mathrm{cm}$ dish and sealed with parafilm. The sealed dishes were maintained in the laboratory in darkness at ambient temperature. Each treatment was replicated three times and experiments were repeated at least twice.

Pollen germination was assessed in the presence of the following tissues (number used): tomato (Lycopersicon esculentum Mill.) leaflets (five), cucumber (Cucumis sativus L.) leaves (one), chrysanthemum [Dendranthema $\times$ grandiflorum (Ramat.) Kitamura] leaves (five), strawberry (Fragaria $\times$ ananassa Duch.) leaflets (five), rose (Rosa spp.) petals (10), and 'Red Delicious' apple flowers (five). The leaves and rose petals were collected from greenhouse-grown plants

Received for publication 28 May 1991. Accepted for publication 9 Oct. 1991. Paper no. 91-10-84, Kentucky Agricultural Experiment Station. The cost of publishing this paper was defrayed in part by the payment of page charges. Under postal regulations, this paper therefore must be hereby marked advertisement solely to indicate this fact. in March and April, and the apple flowers were collected from field-grown trees 'at full bloom. With the exception of the rose petals, all tissues were tested either intact or macerated by light grinding in a mortar and pestle. In addition, to determine if ethylene released upon maceration had an effect, intact tomato leaves were dipped in 1000 ppm 2-chloroethyl phosphonic acid (ethephon) before bioassay.

After $2 \mathrm{~h}$, microphotographs $(x 40)$ of the pollen were taken. Four fields from each agar block were photographed. Total and germinated pollen grains were counted from the photographs, recording only single grains on the agar surface. Grains were classified as germinated when the pollen tube length exceeded the diameter of the grain. Percent germination values were derived for each treatment and tested by analysis of variance. After determining that data transformation was not necessary, treatments means were compared by Dunnett's test.

Intact leaves from the tested species did not affect apple pollen germination (Table 1). However, with the exception of chrysanthemum leaves, macerated leaves inhibited 'Red Delicious' apple pollen germination. Neither apple flowers, macerated or intact, nor rose petals influenced apple pollen germination (data not shown). The pollen of 'Golden Delicious' apple, 'Van' sweet cherry, and 'Friar' plum were also inhibited by the volatiles produced by macerated tomato leaves (Table 2). Thus, the response was not species-specific.

Exposure to elevated levels of ethylene failed to affect pollen germination (data not shown); thus, the response to volatiles produced by macerated leaves was not due to ethylene. Ethylene generation by the ethephon-treated leaves at levels three times that of the macerated tissues was confirmed by GC-FID analysis (data not shown). Ethylene has been reported to have no effect or to promote germination in other species (Buchanan and Biggs, 1969; Sfakiotakis et al., 1972). High CO, levels, which may have developed in the enclosed dishes containing macerated leaf tissues, have been reported to stimulate tulip pollen germination (Sfakiotakis et al., 1972), although stimulation was absent in this study. Although low $\mathrm{O}_{2}$ levels
Table 1. Inhibition of 'Red Delicious' apple pollen germination by leaf tissue as influenced by maceration.

\begin{tabular}{lcc}
\hline \hline Species & Maceration & Germination (\%) \\
\hline Control & - & 56 \\
Tomato & + & $57^{\mathrm{Ns}}$ \\
& & $34^{*}$ \\
Control & - & 66 \\
Cucumber & + & $60^{\mathrm{Ns}}$ \\
& & $46^{*}$ \\
Control & - & 67 \\
Chrysanthemum & + & $63^{\mathrm{Ns}}$ \\
& & $60^{\mathrm{Ns}}$ \\
Control & - & 65 \\
Strawberry & + & $70^{\mathrm{Ns}}$ \\
& & $46^{*}$ \\
Control & + & 57 \\
Apple & $+25^{*}$ \\
Ns,*Nonsignificant or significant by Dunnett's test, \\
$P<0.05$, control vs. treatment.
\end{tabular}

Table 2. Inhibition of 'Red Delicious' and 'Golden Delicious' apple, 'Van' sweet cherry, and 'Friar' plum pollen germination by volatiles from macerated tomato leaves.

\begin{tabular}{lccc}
\hline \hline & & \multicolumn{2}{c}{ Germination (\%) } \\
\cline { 4 - 4 } Species & Cultivar & Control & Volatiles \\
\hline Apple & $\begin{array}{c}\text { Red } \\
\text { Delicious } \\
\end{array}$ & 35 & $19^{*}$ \\
& $\begin{array}{c}\text { Golden } \\
\text { Delicious }\end{array}$ & 45 & $12^{*}$ \\
$\begin{array}{c}\text { Sweet } \\
\text { cherry }\end{array}$ & Van & 22 & $2^{*}$ \\
Plum & Friar & 25 & $8^{*}$ \\
\hline
\end{tabular}

*Significant within each species and cultivar by analysis of variance $\mathrm{F}$ test, $P=0.05$.

may have influenced the responses, subsequent bioassay work with pure volatile compounds (i.e., no leaf tissue) revealed that the macerated tomato leaf volatiles Z-3-hexenal and E-2-hexenal were inhibitory (HamiltonKemp et al., 1991). Thus, altered ethylene, $\mathrm{CO}_{2}$, and $\mathrm{O}_{2}$ levels in the dishes were not solely responsible for the observed inhibition of pollen germination. Stimulatory effects similar to those described by French et al. (1979) were not observed. Our work did not separate inhibitory effects on germination from effects on tube elongation.

\section{Literature Cited}

Buchanan, D.W. and R.H. Biggs. 1969. Peach fruit abscission and pollen germination as influenced by ethylene and 2-chloroethane phosphonic acid. J. Amer. Soc. Hort. Sci. 94:327329.

French, R.C., C.L. Graham, R.A. Long, and A.W. Gale. 1979. Effect of nonanal and related fungal spore stimulators on germination of pollen of several Pinus species. J. Agr. Food Chem. 27:184-187.

Hamilton-Kemp, T.R., J.H. Loughrin, D.D. Archbold, R.A. Andersen, and D.F. Hildebrand. 1991. Inhibition of pollen germination by volatile compounds including 2-hexenal and 3-hexenal. J. Agr. Food Chem. 32:952-956.

Sfakiotakis, E.M., D.H. Simon, and D.R. Dilley. 1972. Pollen germination and tube growth dependent on carbon dioxide and independent of ethylene. Plant Physiol. 49:963-967. 